Pacific Journal of Mathematic 


\title{
AN ULTRASPHERICAL GENERATING FUNCTION
}

\author{
Fred BRAFMan
}

1. Introduction. Let $P_{n}^{(a, a)}(v)$ denote ultraspherical polynomials and let

$$
\begin{aligned}
& w=2(v-t)\left(1-2 v t+t^{2}\right)^{-1 / 2}, \\
& g=1-2 v t+t^{2}, \\
& y=-t u\left(1-2 v t+t^{2}\right)^{-1 / 2}, \\
& r=\left(1-2 y w+y^{2}\right)^{1 / 2},
\end{aligned}
$$

with the roots to be those assuming the value 1 for $t=0$. Then this note will prove that

$$
\begin{gathered}
g^{-\alpha-1 / 2}{ }_{2} F_{1}\left[\begin{array}{cc}
c, 1+2 \alpha-c ; & 1-y-r \\
1+\alpha & ;
\end{array}\right]{ }_{2} F_{1}\left[\begin{array}{cc}
c, 1+2 \alpha-c ; & 1+y-r \\
1+\alpha & 2
\end{array}\right] \\
=\sum_{n=0}^{\infty}(1+2 \alpha)_{n}{ }_{3} F_{2}\left[\begin{array}{c}
-n, c, 1+2 \alpha-c ; \\
1+\alpha, 1+2 \alpha ; u
\end{array}\right] F_{n}^{(\alpha, \alpha)}(v) t^{n},
\end{gathered}
$$

valid for $t$ sufficiently small. In (2), $c$ is an arbitrary parameter. Equation (2) is a direct generalization of Rice's result given in [8, equ. 2.14], to which it reduces for $\alpha=0$. (A different generalization of Rice's result is given in [3].) For $c$ the non-positive integer $-k$, the left side of (2) reduces to a product of ultraspherical polynomials:

$$
\begin{array}{rl}
g^{-\alpha-1 / 2} & k ! k ! \\
(1+\alpha)_{k}(1+\alpha)_{k} & P_{k}^{(\alpha, \alpha)}(r+y) P_{k}^{(\alpha, \alpha)}(r-y) \\
= & \sum_{n=0}^{\infty}(1+2 \alpha)_{n} F_{5:}\left[\begin{array}{c}
-n,-k, 1+2 \alpha+k ; \\
1+\alpha, 1+2 \alpha ;
\end{array}\right] P_{n}^{(\alpha, \alpha)}(v) t^{n} .
\end{array}
$$

In addition, this note will show other results on ultraspherical polynomials. Further, it will provide a new way of deriving some results of Weisner. These will be shown later.

The author desires to thank the referee for helpful suggestions regarding the simplification of proof.

2. A preliminary result. It will be established in this section that

Received May 7, 1956, and in revised form November 28, 1956. 
(4) $\left.\sum_{n=0}^{\infty} \frac{(b)_{n}{ }_{2} F_{1}}{n !}\left[\begin{array}{cc}-n, & a ; \\ b & ;\end{array}\right]\right]_{n+1} F_{q}\left[\begin{array}{c}-n, c_{1}, c_{2}, \cdots, c_{n} ; \\ d_{1}, d_{2}, \cdots, d_{q} ;\end{array}\right] t^{n}$

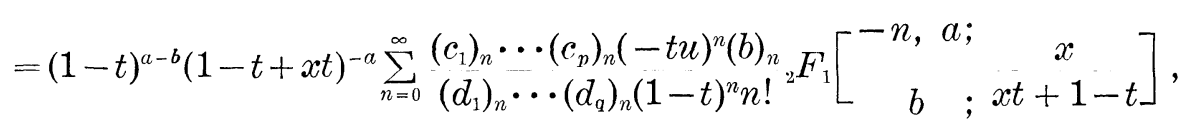

for

$$
|t|<1,|t u /(1-t)|<1, x t+1-t \neq 0, p \leqq q .
$$

Start with

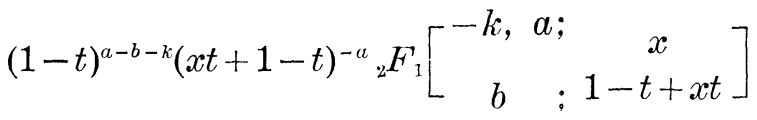

$$
\begin{aligned}
& =(1-t)^{-b-k}(1-x)^{-a}{ }_{2} F_{1}\left[\begin{array}{rr}
b+k, & a ; \\
b & ;(x-1)(1-t)
\end{array}\right]
\end{aligned}
$$

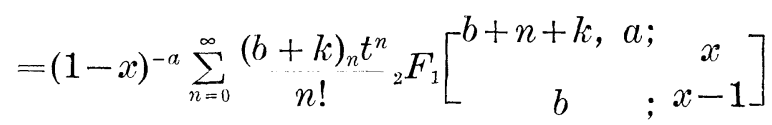

$$
\begin{aligned}
& =\sum_{n=0}^{\infty}(b+k)_{n} t^{n}{ }_{2} F_{1}\left[\begin{array}{cc}
-n-k, a ; & x \\
b & ;
\end{array}\right] .
\end{aligned}
$$

Multiply the first and last lines of (5) by

$$
\begin{gathered}
(b)_{k}\left(c_{1}\right)_{k}\left(c_{2}\right)_{k} \cdots\left(c_{p}\right)_{k}(-t u)^{k} \\
\left(d_{1}\right)_{k}\left(d_{2}\right)_{k} \cdots\left(d_{q}\right)_{k} k !
\end{gathered}
$$

and sum on $k$ from 0 to $\infty$. A shift of indices will then give equation (4). The restrictions given insure the absolute convergence of the various series which are multiplied together.

It should be here noted that (4) includes two results by Weisner as special cases. See [7, equ's. 4.3 and 4.6]. The first follows from (4) by taking

$$
p=1, q=1, c_{1}=d, d_{1}=b
$$

and summing the result by Chaundy's equation 25 in [4].

The second Weisner result follows from (4) by taking

$$
p=0, q=1, d_{1}=b,
$$

and summing by the formula of Rainville as quoted in [5, p. 267, equ. 25]. 
3. Proof of (2). The use of a quadratic transformation [6, p. 9] on a standard form of the ultraspherical polynomials converts them into

$$
P_{n}^{(\alpha, \alpha)}(x)=\frac{(1+\alpha)_{n} z^{-n}{ }_{2} F_{1}}{n !}\left[\begin{array}{c}
-n, \alpha+1 / 2 ; \\
2 \alpha+1 ;
\end{array}\right.
$$

with $2 x=z+1 / z$. This is equivalent to a formula by Weisner [7, p. 1038]. Let

$$
v=\frac{1}{2}(2-x)(1-x)^{-1 / 2}, \quad a=\alpha+1 / 2, \quad b=2 \alpha+1,
$$

replace $t$ by $t(1-x)^{-1 / 2}$ in (4), and let $w, g, y, r$ be defined by (1). Then (4) becomes

$$
\begin{gathered}
\sum_{n=0}^{\infty} \begin{array}{c}
(1+2 \alpha)_{n} \\
(1+\alpha)_{n}{ }_{p+1} F_{q}
\end{array}\left[\begin{array}{c}
-n, c_{1}, \cdots, c_{p} ; \\
d_{1}, \cdots, d_{q} ;
\end{array}\right] P_{n}^{(\alpha, \alpha)}(v) t^{n} \\
=g^{-\alpha-1 / 2} \sum_{n=0}^{\infty} \frac{\left(c_{1}\right)_{n} \cdots\left(c_{p}\right)_{n}}{\left(d_{1}\right)_{n} \cdots\left(d_{q}\right)_{n}} y^{n} \frac{(1+2 \alpha)_{n}}{(1+\alpha)_{n}} P_{n}^{(\alpha, \alpha)}(w) .
\end{gathered}
$$

In (11), take

$$
p=2, q=2, d_{1}=1+\alpha, d_{2}=1+2 \alpha, c_{1}=c, c_{2}=1+2 \alpha-c
$$

and apply the formula given in [2, equ. 17]. Result (2) above follows immediately.

For an additional result from (11), take

$$
p=0, \quad q=2, \quad d_{1}=1+\alpha, \quad d_{2}=1+2 \alpha,
$$

and use the result from Bateman [1], that

$$
\begin{gathered}
{ }_{0} F_{1}\left(-; 1+\alpha ; \frac{y(w-1)}{2}\right){ }_{0} F_{1}\left(-; 1+\alpha ; \frac{y(w+1)}{2}\right) \\
=\sum_{n=0}^{\infty} \frac{P_{n}^{(\alpha, \alpha)}(w) y^{n}}{(1+\alpha)_{n}(1+\alpha)_{n}} .
\end{gathered}
$$

This gives

$$
\begin{array}{r}
g^{-\alpha-1 / 2}{ }_{0} F_{1}\left(-; 1+\alpha ; \frac{y(w-1)}{2}\right){ }_{0} F_{1}\left(-; 1+\alpha ; \begin{array}{c}
y(w+1) \\
2
\end{array}\right) \\
=\sum_{n=0}^{\infty}(1+2 \alpha)_{n}{ }_{1} F_{2}\left[\begin{array}{c}
-n \\
(1+\alpha)_{n}
\end{array}\right] u P_{n}^{(\alpha, \alpha)}(v) t^{n}
\end{array}
$$


Two further results are obtainable from (11) on ultraspherical polynomials. However they are both special cases of the results by Weisner mentioned above, and so are merely presented here for completeness. For the first, take in (11)

$$
p=q=1, \quad d_{1}=1+2 \alpha, \quad c_{1}=\alpha,
$$

and sum the result by $[2$, equ. (18)] to get

$$
\begin{aligned}
& g^{-\alpha-1 / 2}(1-y w)^{-a}{ }_{2} F_{1}\left[\begin{array}{cc}
a / 2,(a+1) / 2 ; & y^{2}\left(w^{2}-1\right) \\
1+\alpha \quad ; & (1-y w)^{2}
\end{array}\right] \\
& =\sum_{n=0}^{\infty} \frac{(1+2 \alpha)_{n}}{(1+\alpha)_{n}} F_{1}\left[\begin{array}{c}
-n, a ; \\
1+2 \alpha ;
\end{array}\right] P_{n}^{(\alpha, \alpha)}(v) t^{n}
\end{aligned}
$$

If $a$ is a non-positive integer $-k$ then (17) becomes

$$
\begin{aligned}
& g^{-\alpha-1 / 2} \frac{r^{k} k !}{(1+\alpha)_{k}} P_{k}^{(\alpha, \alpha)}\left(\frac{1-y w}{r}\right) \\
& \quad=\sum_{n=0}^{\infty} \frac{(1+2 \alpha)_{n}}{(1+\alpha)_{n}} F_{1}\left[\begin{array}{rr}
-n,-k ; & u \\
1+\alpha & ;
\end{array}\right] P_{n}^{(\alpha, \alpha)}(v) t^{n} .
\end{aligned}
$$

For the other result of Weisner's, in (11) take

$$
p=0, \quad q=1, \quad d_{1}=1+2 \alpha,
$$

and sum to get:

$$
\begin{aligned}
g^{-\alpha-1 / 2} e^{y w}{ }_{0} F_{1} & \left(-; 1+\alpha ; \frac{y^{2}\left(w^{2}-1\right)}{4}\right) \\
= & \sum_{n=0}^{\infty}(1+2 \alpha)_{n}{ }_{1} F_{1}\left[\begin{array}{c}
-n ; u \\
1+2 \alpha ;
\end{array}\right] P_{n}^{(a, \alpha)}(v) t^{n} .
\end{aligned}
$$

\section{REFERENCES}

1. H. Bateman, A generalization of the Legendre polynomial, Proc. London Math. Soc. (2), 3, (1905), 111-123.

2. F. Brafman, Generating functions of Jacoli and related polynomials, Proc. Amer. Math. Soc., 2, (1951), 942-949.

3. A generating function for associated Legendre polynomials, submitted to Quart. J. Math., 8, (1957), 81-83.

4. T. W. Chaundy, An extension of hypergeometric functions I, Quart. J. Math. Oxford Ser. 14, (1943), 55-78.

5. Erdelyi, Magnus, Oberhettinger, Tricomi, Higher transcendental functions, Bateman Manuscript Project, vol. 3, McGraw Hill, 1955. 
6. Magnus and Oberhettinger, Special functions of mathematical physics, Chelsea, 1949.

7. L. Weisner, Group-theoretic origin of certain gensrating functions, Pacific J. Math., 5, (1955), 1033-1039.

8. S. O. Rice, Some properties of ${ }_{3} F_{2}(-n, n+1, \zeta ; 1, p ; v)$, Duke Math. J. 6, (1940), 108-119.

WAYNE STATE UNIVERSITY

SOUTHERN ILLINOIS UNIVERSITY 



\title{
PACIFIC JOURNAL OF MATHEMATICS
}

\author{
EDITORS
}

H. L. Royden

Stanford University

Stanford, California

R. A. Beaumont

University of Washington

Seattle 5, Washington
A. L. Whiteman

University of Southern California

Los Angeles 7, California

E. G. Straus

Unıversity of California

Los Angeles 24, California

\section{ASSOCIATE EDITORS}

\author{
E. F. BECKENBACH \\ C. E. BURGESS \\ M. HALL \\ E. HEWITT
}

\author{
A. HORN \\ V. GANAPATHY IYER \\ R. D. JAMES \\ M. S. KNEBELMAN
}

L. NACHBIN
I. NIVEN
T. G. OSTROM
M. M. SCHIFFER

G. SZEKERES

F. WOLF

K. YOSIDA

\section{SUPPORTING INSTITUTIONS}

UNIVERSITY OF BRITISH COLUMBIA

CALIFORNIA INSTITUTE OF TECHNOLOGY

UNIVERSITY OF CALIFORNIA

MON'TANA STATE UNIVERSITY

UNIVERSITY OF NEVADA

OREGON STATE COLLEGE

UNIVERSITY OF OREGON

UNIVERSITY OF SOUTHERN CALIFORNIA

\author{
STANFORD UNIVERSITY \\ UNIVERSITY OF UTAH \\ WASHINGTON STATE COLLEGE \\ UNIVERSITY OF WASHINGTON \\ AMERICAN MATHEMATICAL SOCIETY \\ CALIFORNIA RESEARCH CORPORATION \\ HUGHES AIRCRAFT COMPANY \\ THE RAMO-WOOLDRIDGE CORPORATION
}

Mathematical papers intended for publication in the Pacific Journal of Mathematics should be typewritten (double spaced), and the author should keep a complete copy. Manuscripts may be sent to any of the editors. All other communications to the editors should be addressed to the managing editor, E. G. Straus at the University of California, Los Angeles 24, California.

50 reprints per author of each article are furnished free of charge; additional copies may be obtained at cost in multiples of 50 .

The Pacific Journal of Mathematics is published quarterly, in March, June, September, and December. The price per volume (4 numbers) is $\$ 12.00$; single issues, $\$ 3.50$. Back numbers are available. Special price to individual faculty members of supporting institutions and to individual members of the American Mathematical Society: $\$ 4.00$ per volume; single issues, $\$ 1.25$.

Subscriptions, orders for back numbers, and changes of address should be sent to Pacific Journal of Mathematics, 2120 Oxford Street, Berkeley 4, California.

Printed at Kokusai Bunken Insatsusha (International Academic Printing Co., Ltd.), No. 10, 1-chome, Fujimi-cho, Chiyoda-ku, Tokyo, Japan.

PUBLISHED BY PACIFIC JOURNAL OF MATHEMATICS, A NON-PROFIT CORPORATION

The Supporting Institutions listed above contribute to the cost of publication of this Journal, but they are not owners or publishers and have no responsibility for its content or policies. 


\section{Pacific Journal of Mathematics}

\section{Vol. 7, No. $3 \quad$ March, 1957}

Silvio Aurora, Multiplicative norms for metric rings............... 1279

Ross A. Beaumont and John Richard Byrne, On the construction of

$R$-modules and rings with polynomial multiplication ............ 1305

Fred Brafman, An ultraspherical generating function . . . . . . . . . . . 1319

Howard Ernest Campbell, On the Casimir operator ............... 1325

Robert E. Edwards, Representation theorems for certain functional

operators..................................... 1333

Tomlinson Fort, The five-point difference equation with periodic

coefficients ..................................... 1341

Isidore Heller, On linear systems with integral valued solutions......... 1351

Harry Hochstadt, Addition theorems for solutions of the wave equation in

parabolic coordinates ................................ 1365

James A. Hummel, The coefficient regions of starlike functions . . . . . . . . 1381

Fulton Koehler, Estimates for the eigenvalues of infinite matrices ......... 1391

Henry Paul Kramer, Perturbation of differential operators ............. 1405

R. Sherman Lehman, Development of the mapping function at an analytic

corner .......................................... 1437

Harold Willis Milnes, Convexity of Orlicz spaces.................. 1451

Vikramaditya Singh, Interior variations and some extremal problems for certain classes of univalent functions . . . . . . . . . . . . . . . . 1485

William Lee Stamey, On generalized euclidean and non-euclidean spaces ............................................. 1505

Alexander Doniphan Wallace, Retractions in semigroups .............. 1513

R. L. Wilder, Monotone mappings of manifolds .................. 1519 